\title{
A comparative study of small molecules targeting elF4A
}

\author{
SAI KIRAN NAINENI, ${ }^{1,6}$ RAYELLE ITOUA MAÏGA, ${ }^{1,6}$ REGINA CENCIC, ${ }^{1}$ ANDREA A. PUTNAM, ${ }^{2}$ \\ LUIS A. AMADOR, ${ }^{3}$ ABIMAEL D. RODRIGUEZ, ${ }^{3}$ ECKHARD JANKOWSKY, $^{2}$ and JERRY PELLETIER ${ }^{1,4,5}$ \\ ${ }^{1}$ Department of Biochemistry, McGill University, Montreal, Québec H3G 1Y6, Canada \\ ${ }^{2}$ School of Medicine, Center for RNA Science and Therapeutics, Case Western Reserve University, Cleveland, Ohio 44106, USA \\ ${ }^{3}$ Department of Chemistry, Faculty of Natural Sciences, University of Puerto Rico, San Juan, 00931-3346, Puerto Rico \\ ${ }^{4}$ Department of Oncology, McGill University, Montreal, Québec H4A 3T2, Canada \\ ${ }^{5}$ Rosalind \& Morris Goodman Cancer Research Centre, McGill University, Montreal, Québec H3A 1A3, Canada
}

\begin{abstract}
The PI3K/Akt/mTOR kinase pathway is extensively deregulated in human cancers. One critical node under regulation of this signaling axis is eukaryotic initiation factor (elF) 4F, a complex involved in the control of translation initiation rates. elF4F-dependent addictions arise during tumor initiation and maintenance due to increased elF4F activity-generally in response to elevated PI3K/Akt/mTOR signaling flux. There is thus much interest in exploring elF4F as a small molecule target for the development of new anticancer drugs. The DEAD-box RNA helicase, elF4A, is an essential subunit of elF4F, and several potent small molecules (rocaglates, hippuristanol, pateamine A) affecting its activity have been identified and shown to demonstrate anticancer activity in vitro and in vivo in preclinical models. Recently, a number of new small molecules have been reported as having the capacity to target and inhibit elF4A. Here, we undertook a comparative analysis of their biological activity and specificity relative to the elF4A inhibitor, hippuristanol.
\end{abstract}

Keywords: translation initiation; elF4A; RNA helicase; elF4F; hippuristanol

\section{INTRODUCTION}

Translation, the most energetically expensive process in the cell, plays a major role in gene expression. Dysregulation of this process perturbs several critical cellular networks and can facilitate the establishment of multiple cancer hallmarks including resistance to cell death, activation of invasion and metastasis, induction of angiogenesis, enablement of replicative immortality, deregulated cellular energetics, and altered immune responses and inflammation (Hanahan and Weinberg 2011; Bhat et al. 2015). Perturbations that increase the activity or availability of eukaryotic initiation factor (elF) 4E, a cap-binding protein involved in recruiting ribosomes to mRNA, can selectively stimulate translation of mRNAs that play critical roles in the aforementioned hallmarks to drive tumorigenesis in appropriate contexts (Lazaris-Karatzas et al. 1990; Ruggero et al. 2004; Wendel et al. 2004). elF4E is a subunit of the heterotrimeric elF4F complex and associates with the elF4G subunit; the latter acting as a scaffold that recruits 435 preinitiation complexes (PICs) to mRNAs. The elF4A DEAD-box RNA helicase subunit is a critical component

${ }^{6}$ These authors contributed equally to this work. Corresponding author: jerry.pelletier@mcgill.ca

Article is online at http://www.rnajournal.org/cgi/doi/10.1261/rna. 072884.119. of elF4F and is required to remodel mRNA $5^{\prime}$ leaders in preparation of 43S PIC binding. Mammalian cells encode two elF4A paralogs, elF4A1 and elF4A2, that share $\sim 90 \%$ identity at the amino acid level (Nielsen and Trachsel 1988). Although both elF4A proteins can exchange into the elF4F complex, elF4A1 is essential for cell viability whereas elF4A2 is not (Yoder-Hill et al. 1993; Galicia-Vazquez et al. 2015).

Elevation of c-MYC levels or activation of the PI3K/Akt/ mTOR signaling pathway increases elF4F levels and leads to selective translation stimulation of many pro-oncogenic mRNAs (Lin et al. 2008). In turn, translation of c-Myc mRNA is elF4F-dependent and targeting elF4F is a powerful way of down-regulating MYC (Robert et al. 2014). Inhibiting elF4E is synthetic lethal with MYC overexpression, offering a unique therapeutic opportunity for drugging MYC-dependent tumors (Lin et al. 2012; Pourdehnad et al. 2013). There is thus much interest in strategies by which to inhibit elF4F in cancer, and the feasibility of this approach has been borne out by experiments undertaken

(C) 2020 Naineni et al. This article is distributed exclusively by the RNA Society for the first 12 months after the full-issue publication date (see http://rnajournal.cshlp.org/site/misc/terms.xhtml). After 12 months, it is available under a Creative Commons License (Attribution-NonCommercial 4.0 International), as described at http:// creativecommons.org/licenses/by-nc/4.0/. 
by several groups (Bhat et al. 2015). Delivery of elF4E-targeting antisense oligonucleotides (ASO) in mouse xenograft models curtails tumor growth and the underlying angiogenic supporting network (Graff et al. 2007). The generation of transgenic mice expressing inducible shRNAs capable of systemically reducing elF4E levels showed that chronic, global suppression of elF4E is well tolerated at the organismal level (Lin et al. 2012). Small molecules that inhibit elF4F activity have been identified from highthroughput screens, and among the more potent ones are those that target elF4A-namely hippuristanol (Hipp), rocaglates, and pateamine $A$ (Cencic et al. 2012; Bhat et al. 2015; Chu and Pelletier 2015).

Hipp (Fig. 1A) has been shown to bind to the elF4A carboxy-terminal domain (CTD) and inhibit RNA interaction by stabilizing elF4A in a closed conformation (Bordeleau et al. 2006; Lindqvist et al. 2008; Sun et al. 2014). Its binding site is not conserved among other DEAD-box RNA helicases, making it a selective elF4A inhibitor (Lindqvist et al. 2008). In contrast, pateamine $A$ and rocaglates stabilize RNA-bound elF4A and deplete elF4A from the elF4F complex (Bordeleau et al. 2005, 2008; Low et al. 2005; Cencic et al. 2009; Iwasaki et al. 2016). All three classes of compounds have been tested in several preclinical cancer models and display single agent activity, have the ability to resensitize drug-resistant tumor cells to chemotherapy, and are tolerated in vivo (Bordeleau et al.

2008; Kuznetsov et al. 2009; Cencic et al. 2013; Chu and Pelletier 2015). Through the identification and characterization of an elF4A1 rocaglate-resistant allele, the anticancer activity of rocaglates has been genetically linked to elF4A1 target engagement (Chu et al. 2016; Iwasaki et al. 2019). There is thus much interest in developing elF4A inhibitors as potential anticancer agents.

Several recent reports have emerged reporting on new small molecule inhibitors of elF4A (Fig. 1B). The marine natural product, elatol, was first isolated as a cytotoxic compound and subsequently reported to inhibit elF4A1mediated ATP hydrolysis in vitro (Peters et al. 2018). However, elatol also induces robust phosphorylation of
elF2 $\alpha$ in MEFs, making it difficult to directly link any in cellula activity of elatol to elF4A1 inhibition (Peters et al. 2018). Elisabatin $A$ (Elis. A) was also identified as an inhibitor of elF4A1 ATPase activity in vitro (Tillotson et al. 2017). The prostaglandin, 15d-PGJ2, has been reported to inhibit translation and when immobilized on a solid support matrix was able to capture elF4A1 (but not elF4G1) from cytoplasmic extracts, suggesting that it interferes with elF4A: elF4G interaction (Kim et al. 2007; Yun et al. 2018). The antifungal agent, 6-aminocholestanol (6-AC), was identified following virtual docking simulations as a potential inhibitor of mammalian and Leishmania elF4A1 (Abdelkrim et al. 2018; Harigua-Souiai et al. 2018). In vitro testing found that 
6-AC blocked the ATPase and helicase activity of mammalian and Leishmania (Li) elF4A1 (Abdelkrim et al. 2018; Harigua-Souiai et al. 2018). Lastly, sanguinarine (SAN) has recently been reported to inhibit elF4A1 ATPase and helicase activity (Jiang et al. 2019). With such an abundance of new elF4A inhibitors, we sought to compare the selectivity and potency of these compounds.

\section{RESULTS AND DISCUSSION}

We first tested the activity of the compounds shown in Figure $1 \mathrm{~B}$ in in vitro translation extracts utilizing a FF/ $\mathrm{HCV} /$ Ren bicistronic mRNA reporter (Fig. 1C, top panel). The HCV IRES serves as an internal control in these experiments since its initiation is not dependent on any of the three elF4F subunits (Fraser and Doudna 2007). In rabbit reticulocyte lysates (RRL), Hipp (10 $\mu \mathrm{M})$ potently inhibited cap-dependent FLuc output while having no effect on HCV IRES-driven RLuc production (Fig. 1C; Supplemental Table S1), as previously reported (Bordeleau et al. 2006). Elatol and elisabatin A had little effect on FLuc or RLuc production when present in extracts at final concentrations of 12.5 or $100 \mu \mathrm{M}$ (Fig. 1C). SAN inhibited FLuc at 5 and $40 \mu \mathrm{M}$ (Fig. 1C). 15d-PGJ2 blocked expression of both cap- and HCV IRES-mediated translation at $100 \mu \mathrm{M}$. 6-AC had no effect on FLuc or RLuc output at $100 \mu \mathrm{M}$ (Fig. 1C). The compounds were also tested in translation extracts prepared from murine Krebs-2 cells (Fig. 1D; Supplemental Table S1). Here, elisabatin A reduced both FLuc and RLuc by $\sim 50 \%$ at $80 \mu \mathrm{M}$ (Fig. 1D). The effects of SAN on FLuc and RLuc expression in Krebs-2 extracts were not as pronounced as in RRL, but nevertheless expression of both luciferases was inhibited at $40 \mu \mathrm{M}$ compared to $5 \mu \mathrm{M}$ (Fig. 1D). 15d-PGJ2 blocked expression of both cap- and HCV IRES-mediated translation at $100 \mu \mathrm{M}$ in Krebs-2 extracts (Fig. 1D). As in RRL, 6-AC had little effect on FLuc or RLuc activity in Krebs-2 extracts (Fig. 1D). With the exception of Hipp or SAN in RRL, these results are not what would be expected for a selective elF4A inhibitor.

A recognized shortcoming of using luciferase as a readout in vitro for assessing the consequences of small molecules on translation is that some compounds can quench the luciferase reaction, or inactivate FLuc enzyme, thus scoring as false-positives in bioluminescent assays (Novac et al. 2004). We therefore directly assessed the ability of compounds to quench FLuc and RLuc activity (Fig. 2A; Supplemental Table S1). For these experiments, FLuc and RLuc are first produced in vitro from the FF/HCV/ Ren mRNA, translation is then blocked by the addition of the elongation inhibitor cycloheximide, the compound of interest is then added, and FLuc and RLuc activities are measured 15 min later. Among the compounds sampled, SAN quenched FLuc activity at both concentrations tested, and 15d-PGJ2 modestly inhibited FLuc output at $100 \mu \mathrm{M}$ (Fig. 2A). These results indicate that the inhibition seen

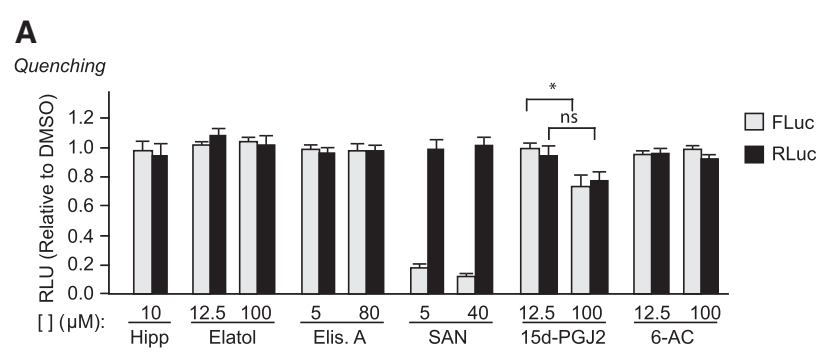

B

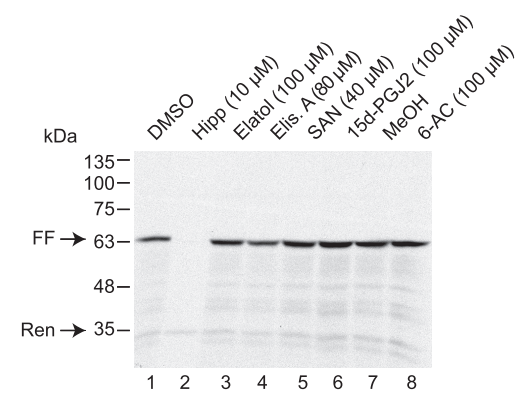

FIGURE 2. Assessment of luciferase quenching activity. (A) Quenching assays were performed by first translating FF/HCV/Ren mRNA in RRL for $1 \mathrm{~h}$, after which cycloheximide $(10 \mu \mathrm{g} / \mathrm{mL})$ was added to stop the reaction. Compounds were then added to the RRL at the indicated final concentrations, incubated at $30^{\circ} \mathrm{C}$ for an additional 15 min, after which time FLuc and RLuc activity were measured. Luciferase activity results are calculated relative to values obtained in the presence of vehicle controls and are expressed as the mean of three biological replicates performed in duplicates. \pm SEM. ns, $P>$ $0.05 ;\left(^{*}\right) 0.05>P>0.01$. (B) Production of [ $\left.{ }^{35} \mathrm{~S}\right]-\mathrm{FLuc}$ and $\left[{ }^{35} \mathrm{~S}\right]-\mathrm{RLuc}$ following in vitro translation of FF/HCV/Ren mRNA in the presence of the indicated compound concentrations. Following translations, samples were processed in Laemmli sample buffer and electrophoresed through an SDS-10\% polyacrylamide gel. The gel was treated with EN ${ }^{3}$ Hance, dried and exposed to X-Omat (Kodak) film. The arrows indicate the position of migration of FLuc and RLuc proteins.

in Figure 1 with SAN on FLuc is likely due to quenching. 15d-PGJ2 showed modest FLuc quenching at $100 \mu \mathrm{M}$, but its behavior in this assay cannot explain the potent inhibition seen in in vitro translation extracts (Fig. 1C,D).

To more directly assess the effects of these compounds on translation, we monitored product formation through the incorporation of ${ }^{35} \mathrm{~S}-\mathrm{Met}$ into FLuc and RLuc in vitro as this provides a readout independent of enzyme activity (Fig. 2B). FLuc is visualized as a molecular species at 62 $\mathrm{kDa}$, whereas RLuc is $36 \mathrm{kDa}$. As previously reported, Hipp inhibits production of FLuc, but not RLuc (Fig. 2B, compare lane 2 to 1 ; Bordeleau et al. 2006). None of the other tested compounds significantly inhibited incorporation of ${ }^{35} \mathrm{~S}$-Met into FLuc or RLuc proteins indicating that under these conditions they are not affecting elF4A1 activity to block translation (Fig. 2B, compare lanes 3-6 to 1 and 8 to 7$)$.

We then sought to assess the behavior of these compounds on elF4A1-mediated helicase activity using a classic gel-based assay that resolves duplexed RNA substrate from single-stranded, unwound product (Rozen et al. 
1990; Rogers et al. 1999). This assay is information-rich as it can identify inhibitors that would impair RNA or ATP binding, ATP hydrolysis, or hinder conformational changes during the unwinding process. As well, direct visualization of the RNA substrates and products is powerful as it provides a quality assurance step that ensures substrate/ product relationships are maintained. For example, contamination of an elF4A preparation by a ribonuclease or phosphatase would result in loss of label on the substrate (dsRNA) with no or sub-stoichiometric amounts of product generated (ssRNA). These problems are not readily detected in solution-based helicase assays that rely solely on gains in fluorescence as readout from a quenched dsRNA substrate (Sommers et al. 2019). The RNA duplex used as substrate in our assay has been previously described and has a $\Delta \mathrm{G}$ of $-17.9 \mathrm{kcal} / \mathrm{mol}$ (Fig. 3A; Rogers et al. 1999). Hipp inhibited elF4A1 helicase activity, as previously doc-

A RNA-1: 5'GGGGAGA (AAAAC) 5 UAGCACCGUAAAGCACGC 3' RNA-11: 3, GUGGCAUUUCG* 5,

B

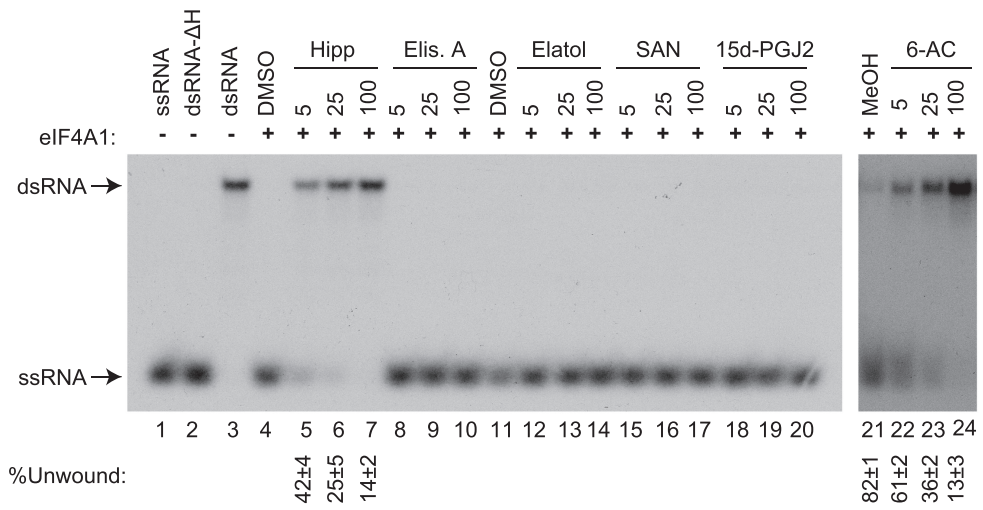

C

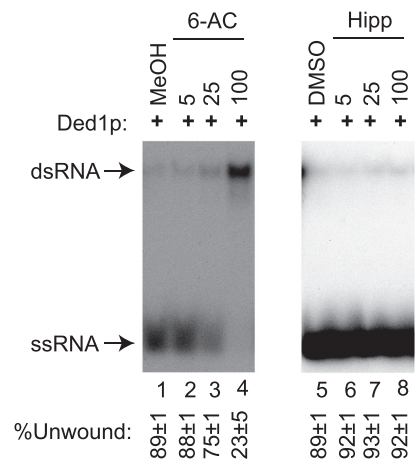

FIGURE 3. Assessing effects of compounds on elF4A1 helicase activity. (A) Sequence of RNA duplex used in this study. The asterisk at the $5^{\prime}$ end of RNA-11 denotes the location of the ${ }^{32} \mathrm{P}$ label. (B) Double-stranded (dsRNA) unwinding activity of elF4A1 in the presence of the indicated compound concentrations. The position of migration of the RNA duplex and single-stranded RNA (ssRNA) molecules is indicated to the left of the panels. Single-stranded RNA-11 was loaded in lane 1 in the absence of elF4A. Denatured dsRNA $\left(\Delta \mathrm{H}\right.$ : performed at $\left.95^{\circ} \mathrm{C}\right)$ was loaded in lane 2 (dsRNA- $\Delta \mathrm{H}$ ) and nondenatured dsRNA was loaded in lane 3 (dsRNA). Results are representative of two biological replicates \pm SEM. (C) Unwinding activity of Ded1 $p$ in the presence of 6-AC or Hipp. $n=2 \pm$ SEM. umented (Fig. 3B, compare lanes 5-7 to 4) (Bordeleau et al. 2006). Elisabatin A, elatol, SAN, and 15d-PGJ2 had no effect on elF4A1 helicase activity up to concentrations of $100 \mu \mathrm{M}$ (Fig. 3B, lanes 8-20). Only 6-AC inhibited efF4A1 helicase activity in a dose-dependent manner (Fig. 3B, compare lanes 22-24 to 21). However, this effect was not specific to elF4A1 since 6-AC also blocked Ded1p activity, a yeast DEAD-box helicase (Fig. 3C, compare lanes 2-4 to 1). Surprisingly, 6-AC had little effect in translation extracts (Fig. 1C,D), a result that could indicate promiscuous binding to multiple targets and titration away from elF4A1 in the more complex setting of in vitro translation assays. In characterizing the effects of 6-AC on the helicase activity of murine and LielF4A, Abdelkrim et al. (2018) observed significant "helicase activity" in the absence of ATP, a result that is inconsistent with the absolute dependency of elF4A 1 on ATP for enzymatic activity (Rogers et al. 1999)—raising the question of what exactly was being affected by $6-A C$ in these previous assays. Taken together, these results indicate that among the tested compounds, only Hipp displayed a behavior consistent with it being a selective elF4A inhibitor.

We have previously shown that JJN3 multiple myeloma cell viability is compromised when exposed to rocaglate, silvestrol, or Hipp (Robert et al. 2014). We found that the most potent compounds were pateamine $A\left(I C_{50}=\right.$ $\sim 2 \mathrm{nM}), C R-1-31-\mathrm{B}\left(\mathrm{IC}_{50}=5 \mathrm{nM}\right)$, and Hipp $\left(\mathrm{IC}_{50}=\sim 0.3 \mu \mathrm{M}\right)$ (Fig. 4A). Elisabatin $\mathrm{A}$ and 6-AC displayed little bioactivity in this assay (Fig. 4A, left panel). Elatol $\left(I \mathrm{C}_{50}=\sim 1.3 \mu \mathrm{M}\right)$ and SAN $\left(\mathrm{IC}_{50}=\sim 2 \mu \mathrm{M}\right)$ were $\sim 4-6$ times less potent than Hipp, whereas $15 \mathrm{~d}$ PGJ2 $\left(I C_{50}=\sim 6 \mu \mathrm{M}\right)$ was $\sim 20$ times less potent than Hipp (Fig. 4A, right panel). A similar rank order was observed with these compounds toward A549 lung cancer cells (Supplemental Fig. S1).

Many compounds can nonspecifically inhibit protein synthesis through activation of the integrated stress response (ISR), an adaptive cellular mechanism that permits cells to respond to, and survive, stress (PakosZebrucka et al. 2016). At the core of this pathway is phosphorylation of elF2 $\alpha$ (performed by one of four kinases) which serves to dampen global protein synthesis while permitting the 
A
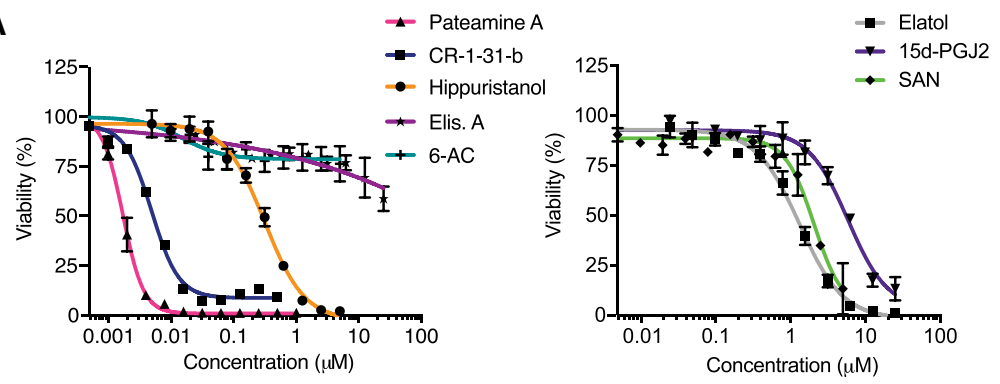

B

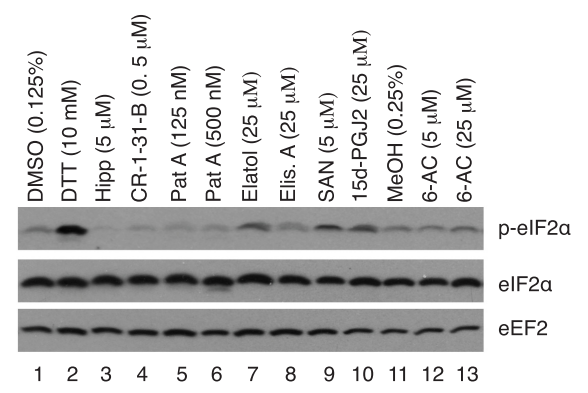

FIGURE 4. Assessing the response of JJN3 cells to putative elF4A inhibitors. (A) JJN3 cells were treated with increasing doses of the indicated compounds for $48 \mathrm{~h}$. Viability was measured using the CellTiter Glo assay. Results are expressed relative to vehicle-treated cells. $n=3 \pm$ SEM. (B) Assessing elF2 $\alpha$ phosphorylation status in JJN-3 cells exposed to the indicated compound concentrations for $90 \mathrm{~min}$. Western blots were probed with antibodies targeting the proteins indicated to the right.

expression of a select choice of mRNAs. Since elatol has previously been shown to activate the ISR (Peters et al. 2018), we wished to assess this in JJN-3 cells and determine if any other compound also activated this response. DTT is a potent inducer of the ISR and served as a positive control in this assay (Fig. 4B, compare lane 2 to 1). Neither Hipp, the rocaglate CR-1-31-B, nor pateamine $A$ induced elF2 $\alpha$ phosphorylation (compare lanes 3-6 to 1). Elatol, SAN, and 15d-PGJ2 all induced elF2 $\alpha$ phosphorylation (compare lanes 7-10 to 1 ), whereas elisabatin $A$ and 6 AC did not.

In sum, with the exception of Hipp, the results we obtained are not what would be expected for an elF4A inhibitor. Indeed, SAN is known to have quite promiscuous bioactivity - with effects ranging from antioxidant, anti-inflammatory, proapoptotic and growth inhibitory activities on tumor cells (Galadari et al. 2017). It nonspecifically inhibits a large number of cellular processes and biological targets, among which are quadruplexes of human telomeres and of the c-MYC promoter (Ghosh et al. 2013), the PTP1B phosphatase (Zeder-Lutz et al. 2012), Stat3 (Sun et al. 2012), Bcl-XL (Bernardo et al. 2008), mitogen-activated protein kinase phosphatase-1 (Vogt et al. 2005), and NF-KB (Chaturvedi et al. 1997). It thus appears that SAN is likely a pan-assay interference compound (PAIN) (Baell and Holloway 2010).

$15 \mathrm{~d}-\mathrm{PGJ} 2$ is a cyclopentenone prostaglandin possessing $\alpha, \beta$-unsaturated carbonyl groups that can favor Michael addition reactions to form covalent adducts with exposed nucleophiles, such as presented by cysteine thiol residues and 15d-PGJ2 has been shown to interact with elF4A1 Cys264 (Kim et al. 2007). Perhaps this explains why $15 d-P G J 2$ inhibits FLuc in vitro when assessing translation via luciferase readout (Fig. 1C,D) (but no quenching activity) versus no effect when $\left[{ }^{35} \mathrm{~S}\right]-$ Met incorporation is used to monitor translation (Fig. 2B). We have previously observed this behavior when characterizing hits from a previous highthroughput screening assay for translation inhibitors (Novac et al. 2004) and postulate it might be a consequence of a compound interfering with protein folding during synthesis -in which case enzymatic-based readouts score these as false-positives. The large target spectrum of $15 d-P G J 2$ is borne out by a recent proteomic study of endothelial cells exposed to $5 \mu \mathrm{M}$ 15d-PGJ2 for $4 \mathrm{~h}$ (far below the concentration at which effects on translation are reported), where 358 target proteins were identified, among which were many initiation (elF4A1, elF4G1, elF4G3, elF3B elF3D, elF3H, elF3F) and elongation (EF1D, EF2, EF1G, mitochondrial EF-Tu) translation factors (Marcone and Fitzgerald 2013). The physiological concentrations of $15 d-$ PGJ2 in body fluids has been reported to be in the nanomolar range-far lower than the concentrations required to inhibit translation in vitro (Morgenstern et al. 2018).

Elatol has been reported to inhibit elF4A1 ATPase activity and has a 2:1 binding stoichiometry to elF4A1 with a $K_{D}$ of $2 \mu \mathrm{M}$ in vitro (Peters et al. 2018). It is cytotoxic to cells, a property that we have confirmed (Fig. 4A; Peters et al. 2018). Elatol inhibits gene expression but there is no evidence that it does so in cellula by primarily targeting elF4A1. Oddly, exposure of cells to $2 \mu \mathrm{M}$ elatol for $2 \mathrm{~h}$ caused no significant change in translating polysomes (Peters et al. 2018), an effect that should have been immediate and pronounced (as observed with silvestrol in that same experiment), if elF4A1 were the primary target. Rather, extended periods of exposure time (8-16 h) were required to observe inhibition of polysomes and cap-dependent translation. Since translational responses to inhibitors are very rapid (5-15 $\mathrm{min})$, it becomes difficult to ascertain if the reported inhibition of translation by elatol occurring $8 \mathrm{~h}$ following compound exposure is not a secondary consequence of other processes being targeted (Peters et al. 2018). Elatol has been reported to robustly phosphorylate elF2 $\alpha$ (Peters et al. 2018) (a result we have confirmed, see Fig. 4A) and this, in and of itself, could 
explain the translation inhibitory activity of this compound in cells. In our hands, elisabatin A did not show any activity that would suggest it to be a translation inhibitor. Allolaurinterol has also been reported to be an inhibitor of elF4A1 (Tillotson et al. 2017) but due to limitations in compound availability, we have been unable to assess its activity as a translation initiation inhibitor.

We are concerned about the reproducibility of some of the assays that were used to identify and/or characterize the activity of the compounds described herein. Firstly, as far as we can assess, previous studies that identified elatol, elisabatin A, and 6-AC as elF4A1 inhibitors used the malachite green-based assay to score for inhibition of ATPase activity. The recombinant elF4A1 preparations used in several of these studies are reported to have been isolated via a single affinity chromatography steptaking advantage of an engineered $\mathrm{His}_{6}$ tag (Abdelkrim et al. 2018; Harigua-Souiai et al. 2018; Peters et al. 2018). Although the increase in specific activity following immobilized metal-affinity purification (IMAC) can be extremely high, it does not yield protein preparations that are free of contaminants. For example, endogenous bacterial proteins containing adjacent histidine residues will be copurified (Bornhorst and Falke 2000). Case in point, E. coli RNA chaperone $\mathrm{Hfq}$ is a hexamer that harbors four histidine residues per subunit and is a known contaminant of IMAC purifications (Milojevic et al. 2013). Since, elF4A1 has a weak catalytic ATP turnover rate (kcat: $\sim 1-3 / \mathrm{min}$ ) (Lorsch and Herschlag 1998), even a minor contaminant with a high kcat could confuse interpretation of the results (for example, if a compound under study inhibited the contaminant). In our hands, we have found it more rigorous when purifying elF4A1 to include, at a minimum, an additional ion exchange chromatography step, following the IMAC step. It may also be that some of the reported activities of these compounds (Fig. 1B) are context-dependent. In sum, although some of the compounds tested herein (Fig. 1B) have been reported to bind to elF4A1 or interfere with elF4A1 activity, until genetic evidence is obtained linking physiological responses to elF4A1 inhibition, we urge caution in using these as reagents to selectivity probe for elF4A1 activity.

\section{MATERIALS AND METHODS}

\section{Compounds}

The synthesis of Hipp has been previously described (Somaiah et al. 2014). Elatol was synthesized as previously described and was a kind gift from Tyler Fulton, Carina Jette, and Dr. Brian Stoltz (Caltech) (White et al. 2008). Sanguinarine and $15 d-\Delta^{12,14}$ prostaglandin-J2 were purchased from Tocris Bioscience and Enzo Life Sciences, respectively. Elisabatin A was purified from the West Indian sea whip as previously described (Rodríguez et al. 1999). 6- $\alpha$-aminocholestanol was custom synthesized by
Toronto Research Chemicals. All compounds were resuspended in DMSO, with the exception of 6 - $\alpha$-aminocholestanol which was in methanol. All stocks were stored at $-80^{\circ} \mathrm{C}$.

\section{Cell viability assays}

JJN3 cells were maintained in RPMI media supplemented with $10 \%$ BGSS. For viability assays, JJN3 cells were seeded at 500,000 cells $/ \mathrm{mL}$ in 96 -well plates with the indicated drug concentrations for $48 \mathrm{~h}$. Cell viability was determined using CellTiterGlo (Promega). IC 50 values of each drug were assessed using a four-parameter nonlinear curve-fit regression with GraphPad Prism 7 (GraphPad Software).

\section{In vitro transcriptions and translations}

In vitro translation assays were performed in rabbit reticulocyte (RRL) or Krebs-2 extracts as previously described (Novac et al. 2004). Briefly, linearized pSP/FF/HCV/Ren DNA template was transcribed in vitro using SP6 RNA polymerase (NEB). Capped FF/HCV/Ren mRNA was used at a final concentration of 5-10 $\mu \mathrm{g} / \mathrm{mL}$ in RRL and Krebs- 2 extracts. Firefly and renilla enzymatic activities were assessed on a Berthold Lumat LB 9507 luminometer (Berthold technologies). $\left.{ }^{35} \mathrm{~S}\right]$-methionine $(1175 \mathrm{Ci} / \mathrm{mmol}$, PerkinElmer) was used to monitor production of newly synthesized luciferase proteins in RRL. Proteins were separated on SDS/10\% polyacrylamide gels, which were subsequently treated with $\mathrm{EN}^{3}$ Hance, dried, and exposed to film (Kodak).

\section{Purification of recombinant elF4A1}

Recombinant mouse $\mathrm{His}_{6}$-elF4Al protein was expressed in E. coli strain BL21(DE3)/pLysS. Transformed bacteria were inoculated into LB medium and grown overnight, then diluted 1:10 the following morning and grown at $37^{\circ} \mathrm{C}$ until an $\mathrm{OD}_{600}$ of 0.6 was reached. The induction was performed using $1 \mathrm{mM}$ IPTG at $37^{\circ} \mathrm{C}$ for $3 \mathrm{~h}$. After harvesting, cells were lysed by sonication and the insoluble material removed by centrifugation at $25,000 \mathrm{~g}$ for $40 \mathrm{~min}$. The supernatant was applied on a $\mathrm{Ni}^{2+}$-NTA agarose column (Qiagen), the eluted material dialyzed, and further purified on a Q-Sepharose fast flow matrix (GE Healthcare) as previously described (Cencic et al. 2007).

\section{RNA helicase assays}

Helicase activity was assessed using [ $\left.{ }^{32} \mathrm{P}\right]$-labeled RNA probe (RNA-1/RNA-11 duplex) and elF4A1 $(0.56 \mu \mathrm{M})$ or Ded1p $(0.5 \mu \mathrm{M})$, essentially as previously described (Rogers et al. 1999). In short, the reaction was prepared by the addition of $2 \mu \mathrm{M}\left[{ }^{32} \mathrm{P}\right]$ labeled duplex in $1 \times$ helicase buffer $[20 \mathrm{mM}$ Hepes- $\mathrm{KOH}(\mathrm{pH}$ 7.5), $70 \mathrm{mM} \mathrm{KCl}, 2 \mathrm{mM}$ DTT, $1 \mathrm{mM} \mathrm{Mg}(\mathrm{OAc})_{2}$ ], $20 \mu \mathrm{g}$ of acetylated BSA (Ambion), and $1 \mathrm{mM} \mathrm{ATP}$. Reactions were incubated at $35^{\circ} \mathrm{C}$ for $15 \mathrm{~min}$ and stopped by the addition of $1 \times$ Stop Solution $(10 \%$ glycerol, 0.2\% SDS, 2 mM EDTA). Reaction components were separated on a $12 \%$ polyacrylamide gel (29:1; acrylamide/bisacrylamide), dried and quantitated using the Typhoon Trio Imager (GE Healthcare). Gels were also exposed to film (Kodak X-Omat). 


\section{Immunoblotting}

Cells were washed in PBS and lysed in protease inhibitor-enriched RIPA buffer $(20 \mathrm{mM}$ Tris- $\mathrm{HCl}$ [pH 7.6], $100 \mathrm{mM} \mathrm{NaCl}, 1 \mathrm{mM}$ EDTA, 1 mM EGTA, 1\% NP40, 0.5\% sodium deoxycholate, $0.1 \%$ SDS, $1 \mathrm{mM}$ PMSF, $4 \mu \mathrm{g} / \mathrm{mL}$ aprotinin, $2 \mu \mathrm{g} / \mathrm{mL}$ leupeptin, $2 \mu \mathrm{g} / \mathrm{mL}$ pepstatin). Proteins were resolved on a $10 \%$ polyacrylamide gel and transferred to a PVDF membrane (Bio-Rad). Antibodies against p-elF2 $\alpha$ (Ser51), total elF2 $\alpha$, and eEF2 (\#9721, \#5353, and \#2332, respectively) were obtained from Cell Signaling Technologies.

\section{SUPPLEMENTAL MATERIAL}

Supplemental material is available for this article.

\section{ACKNOWLEDGMENTS}

We are grateful to Tyler Fulton, Carina Jette, and Dr. Brian Stoltz (Caltech) for their generous gift of elatol. This research was supported by a grant from the Canadian Institutes of Health Research (FDN-148366) to J.P.

Received August 14, 2019; accepted January 30, 2020.

\section{REFERENCES}

Abdelkrim YZ, Harigua-Souiai E, Barhoumi M, Banroques J, Blondel A, Guizani I, Tanner NK. 2018. The steroid derivative 6-aminocholestanol inhibits the DEAD-box helicase elF4A (LielF4A) from the Trypanosomatid parasite Leishmania by perturbing the RNA and ATP binding sites. Mol Biochem Parasitol 226: 9-19. doi:10 .1016/j.molbiopara.2018.10.001

Baell JB, Holloway GA. 2010. New substructure filters for removal of pan assay interference compounds (PAINS) from screening libraries and for their exclusion in bioassays. J Med Chem 53: 27192740. doi:10.1021/jm901137j

Bernardo PH, Wan KF, Sivaraman T, Xu J, Moore FK, Hung AW, Mok HY, Yu VC, Chai CL. 2008. Structure-activity relationship studies of phenanthridine-based Bcl- $X_{L}$ inhibitors. J Med Chem 51: 6699-6710. doi:10.1021/jm8005433

Bhat M, Robichaud N, Hulea L, Sonenberg N, Pelletier J, Topisirovic I. 2015. Targeting the translation machinery in cancer. Nat Rev Drug Discov 14: 261-278. doi:10.1038/nrd4505

Bordeleau ME, Matthews J, Wojnar JM, Lindqvist L, Novac O, Jankowsky E, Sonenberg N, Northcote P, Teesdale-Spittle P, Pelletier J. 2005. Stimulation of mammalian translation initiation factor elF4A activity by a small molecule inhibitor of eukaryotic translation. Proc Natl Acad Sci 102: 10460-10465. doi:10.1073/ pnas.0504249102

Bordeleau ME, Mori A, Oberer M, Lindqvist L, Chard LS, Higa T, Belsham GJ, Wagner G, Tanaka J, Pelletier J. 2006. Functional characterization of IRESes by an inhibitor of the RNA helicase elF4A. Nat Chem Biol 2: 213-220. doi:10.1038/nchem bio776

Bordeleau ME, Robert F, Gerard B, Lindqvist L, Chen SM, Wendel HG, Brem B, Greger H, Lowe SW, Porco JA, et al. 2008. Therapeutic suppression of translation initiation modulates chemosensitivity in a mouse lymphoma model. J Clin Invest 118: 2651-2660. doi:10.1172/JCl34753
Bornhorst JA, Falke JJ. 2000. Purification of proteins using polyhistidine affinity tags. Methods Enzymol 326: 245-254. doi:10.1016/ S0076-6879(00)26058-8

Cencic R, Robert F, Pelletier J. 2007. Identifying small molecule inhibitors of eukaryotic translation initiation. Methods Enzymol 431: 269-302. doi:10.1016/S0076-6879(07)31013-6

Cencic R, Carrier M, Galicia-Vázquez G, Bordeleau ME, Sukarieh R, Bourdeau A, Brem B, Teodoro JG, Greger H, Tremblay ML, et al. 2009. Antitumor activity and mechanism of action of the cyclopenta[b]benzofuran, silvestrol. PLOS ONE 4: e5223. doi:10 .1371/journal.pone.0005223

Cencic R, Galicia-Vázquez G, Pelletier J. 2012. Inhibitors of translation targeting eukaryotic translation initiation factor 4A. Methods Enzymol 511: 437-461. doi:10.1016/B978-0-12-396546-2 .00020-6

Cencic R, Robert F, Galicia-Vázquez G, Malina A, Ravindar K, Somaiah R, Pierre P, Tanaka J, Deslongchamps P, Pelletier J. 2013. Modifying chemotherapy response by targeted inhibition of eukaryotic initiation factor 4A. Blood Cancer J 3: e128. doi:10 $.1038 /$ bcj.2013.25

Chaturvedi MM, Kumar A, Darnay BG, Chainy GB, Agarwal S, Aggarwal BB. 1997. Sanguinarine (pseudochelerythrine) is a potent inhibitor of NF- $\kappa B$ activation, I $\kappa$ B $\alpha$ phosphorylation, and degradation. J Biol Chem 272: 30129-30134. doi:10.1074/jbc.272.48 .30129

Chu J, Pelletier J. 2015. Targeting the elF4A RNA helicase as an antineoplastic approach. Biochim Biophys Acta 1849: 781-791. doi:10.1016/j.bbagrm.2014.09.006

Chu J, Galicia-Vázquez G, Cencic R, Mills JR, Katigbak A, Porco JA Jr, Pelletier J. 2016. CRISPR-mediated drug-target validation reveals selective pharmacological inhibition of the RNA helicase, elF4A. Cell Rep 15: 2340-2347. doi:10.1016/j.celrep 2016.05.005

Fraser CS, Doudna JA. 2007. Structural and mechanistic insights into hepatitis C viral translation initiation. Nat Rev Microbiol 5: 29-38. doi:10.1038/nrmicro1558

Galadari S, Rahman A, Pallichankandy S, Thayyullathil F. 2017. Molecular targets and anticancer potential of sanguinarine-a benzophenanthridine alkaloid. Phytomedicine 34: 143-153. doi: 10.1016/j.phymed.2017.08.006

Galicia-Vázquez G, Chu J, Pelletier J. 2015. elF4All is dispensable for miRNA-mediated gene silencing. RNA 21: 1826-1833. doi:10 $.1261 /$ rna.052225.115

Ghosh S, Pradhan SK, Kar A, Chowdhury S, Dasgupta D. 2013. Molecular basis of recognition of quadruplexes human telomere and c-myc promoter by the putative anticancer agent sanguinarine. Biochim Biophys Acta 1830: 4189-4201. doi:10.1016/j .bbagen.2013.03.027

Graff JR, Konicek BW, Vincent TM, Lynch RL, Monteith D, Weir SN, Schwier P, Capen A, Goode RL, Dowless MS, et al. 2007. Therapeutic suppression of translation initiation factor elF4E expression reduces tumor growth without toxicity. J Clin Invest 117: 2638-2648. doi:10.1172/JCI32044

Hanahan D, Weinberg RA. 2011. Hallmarks of cancer: the next generation. Cell 144: 646-674. doi:10.1016/j.cell.2011.02.013

Harigua-Souiai E, Abdelkrim YZ, Bassoumi-Jamoussi I, Zakraoui O, Bouvier G, Essafi-Benkhadir K, Banroques J, Desdouits N, Munier-Lehmann H, Barhoumi M, et al. 2018. Identification of novel leishmanicidal molecules by virtual and biochemical screenings targeting Leishmania eukaryotic translation initiation factor 4A. PLoS Negl Trop Dis 12: e0006160. doi:10.1371/journal.pntd .0006160

Iwasaki S, Floor SN, Ingolia NT. 2016. Rocaglates convert DEAD-box protein elF4A into a sequence-selective translational repressor. Nature 534: 558-561. doi:10.1038/nature17978 
Iwasaki S, Iwasaki W, Takahashi M, Sakamoto A, Watanabe C Shichino Y, Floor SN, Fujiwara K, Mito M, Dodo K, et al. 2019. The translation inhibitor rocaglamide targets a bimolecular cavity between elF4A and polypurine RNA. Mol Cell 73: 738-748 e739. doi:10.1016/j.molcel.2018.11.026

Jiang C, Tang W, Ding L, Tan R, Li X, Lu L, Jiang J, Cui Z, Tang Z, Li W, et al. 2019. Targeting the $\mathrm{N}$ terminus of elF4Al for inhibition of its catalytic recycling. Cell Chem Biol 26: 1417-1426.e5. doi:10 .1016/j.chembiol.2019.07.010

Kim WJ, Kim JH, Jang SK. 2007. Anti-inflammatory lipid mediator 15d-PGJ2 inhibits translation through inactivation of elF4A. EMBO J 26: 5020-5032. doi:10.1038/sj.emboj.7601920

Kuznetsov G, Xu Q, Rudolph-Owen L, Tendyke K, Liu J, Towle M, Zhao N, Marsh J, Agoulnik S, Twine N, et al. 2009. Potent in vitro and in vivo anticancer activities of des-methyl, des-amino pateamine $A$, a synthetic analogue of marine natural product pateamine A. Mol Cancer Ther 8: 1250-1260. doi:10.1158/15357163.MCT-08-1026

Lazaris-Karatzas A, Montine KS, Sonenberg N. 1990. Malignant transformation by a eukaryotic initiation factor subunit that binds to mRNA 5' cap. Nature 345: 544-547. doi:10.1038/345544a0

Lin CJ, Cencic R, Mills JR, Robert F, Pelletier J. 2008. c-Myc and elF4F are components of a feedforward loop that links transcription and translation. Cancer Res 68: 5326-5334. doi:10.1158/0008-5472 .CAN-07-5876

Lin CJ, Nasr Z, Premsrirut PK, Porco JA Jr, Hippo Y, Lowe SW, Pelletier J. 2012. Targeting synthetic lethal interactions between Myc and the elF4F complex impedes tumorigenesis. Cell Rep 1: 325-333. doi:10.1016/j.celrep.2012.02.010

Lindqvist $L$, Oberer M, Reibarkh M, Cencic R, Bordeleau ME, Vogt E, Marintchev A, Tanaka J, Fagotto F, Altmann M, et al. 2008. Selective pharmacological targeting of a DEAD box RNA helicase. PLOS ONE 3: e1583. doi:10.1371/journal.pone.0001583

Lorsch JR, Herschlag D. 1998. The DEAD box protein elF4A. 1. A minimal kinetic and thermodynamic framework reveals coupled binding of RNA and nucleotide. Biochemistry 37: 2180-2193. doi:10 .1021/bi972430g

Low WK, Dang Y, Schneider-Poetsch T, Shi Z, Choi NS, Merrick WC, Romo D, Liu JO. 2005. Inhibition of eukaryotic translation initiation by the marine natural product pateamine A. Mol Cell 20: 709-722. doi:10.1016/j.molcel.2005.10.008

Marcone S, Fitzgerald DJ. 2013. Proteomic identification of the candidate target proteins of 15-deoxy-delta12,14-prostaglandin $\mathrm{J}_{2}$. Proteomics 13: 2135-2139. doi:10.1002/pmic.201200289

Milojevic T, Sonnleitner E, Romeo A, Djinović-Carugo K, Bläsi U. 2013. False positive RNA binding activities after Ni-affinity purification from Escherichia coli. RNA Biol 10: 1066-1069. doi:10.4161/rna .25195

Morgenstern J, Fleming T, Kadiyska I, Brings S, Groener JB, Nawroth P, Hecker M, Brune M. 2018. Sensitive mass spectrometric assay for determination of 15 -deoxy- $\Delta^{12,14}$-prostaglandin $J_{2}$ and its application in human plasma samples of patients with diabetes. Anal Bioanal Chem 410: 521-528. doi:10.1007/s00216017-0748-1

Nielsen PJ, Trachsel H. 1988. The mouse protein synthesis initiation factor 4A gene family includes two related functional genes which are differentially expressed. EMBO J 7: 2097-2105. doi:10.1002/j .1460-2075.1988.tb03049.x

Novac O, Guenier AS, Pelletier J. 2004. Inhibitors of protein synthesis identified by a high throughput multiplexed translation screen. Nucleic Acids Res 32: 902-915. doi:10.1093/nar/gkh235

Pakos-Zebrucka K, Koryga I, Mnich K, Ljujic M, Samali A, Gorman AM. 2016. The integrated stress response. EMBO Rep 17: 1374-1395. doi:10.15252/embr.201642195
Peters TL, Tillotson J, Yeomans AM, Wilmore S, Lemm E, JiménezRomero C, Amador LA, Li L, Amin AD, Pongtornpipat $P$, et al. 2018. Target-based screening against elF4A1 reveals the marine natural product elatol as a novel inhibitor of translation initiation with in vivo antitumor activity. Clin Cancer Res 24: 4256-4270. doi:10.1158/1078-0432.CCR-17-3645

Pourdehnad M, Truitt ML, Siddiqi IN, Ducker GS, Shokat KM, Ruggero D. 2013. Myc and mTOR converge on a common node in protein synthesis control that confers synthetic lethality in Myc-driven cancers. Proc Natl Acad Sci 110: 11988-11993. doi:10.1073/pnas.1310230110

Robert F, Roman W, Bramoullé A, Fellmann C, Roulston A, Shustik C, Porco JA Jr, Shore GC, Sebag M, Pelletier J. 2014. Translation initiation factor elF4F modifies the dexamethasone response in multiple myeloma. Proc Natl Acad Sci 111: 13421-13426. doi:10 .1073/pnas. 1402650111

Rodríguez AD, Ramírez C, Rodríguez II. 1999. Elisabatins A and B: new amphilectane-type diterpenes from the West Indian sea whip Pseudopterogorgia elisabethae. J Nat Prod 62: 997-999. doi:10 .1021/np990090p

Rogers GW Jr, Richter NJ, Merrick WC. 1999. Biochemical and kinetic characterization of the RNA helicase activity of eukaryotic initiation factor 4A. J Biol Chem 274: 12236-12244. doi:10.1074/jbc.274 .18 .12236

Rozen F, Edery I, Meerovitch K, Dever TE, Merrick WC, Sonenberg N. 1990. Bidirectional RNA helicase activity of eucaryotic translation initiation factors 4A and 4F. Mol Cell Biol 10: 1134-1144. doi:10 .1128/MCB.10.3.1134

Ruggero D, Montanaro L, Ma L, Xu W, Londei P, Cordon-Cardo C, Pandolfi PP. 2004. The translation factor elF-4E promotes tumor formation and cooperates with c-Myc in lymphomagenesis. Nat Med 10: 484-486. doi:10.1038/nm1042

Somaiah R, Ravindar K, Cencic R, Pelletier J, Deslongchamps P. 2014. Synthesis of the antiproliferative agent hippuristanol and its analogues from hydrocortisone via $\mathrm{Hg}(\mathrm{II})$-catalyzed spiroketalization: structure-activity relationship. J Med Chem 57: 2511-2523. doi: 10.1021/jm401799j

Sommers JA, Kulikowicz T, Croteau DL, Dexheimer T, Dorjsuren D, Jadhav A, Maloney DJ, Simeonov A, Bohr VA, Brosh RM Jr. 2019. A high-throughput screen to identify novel small molecule inhibitors of the Werner Syndrome Helicase-Nuclease (WRN). PLoS One 14: e0210525. doi:10.1371/journal.pone.0210525

Sun M, Liu C, Nadiminty N, Lou W, Zhu Y, Yang J, Evans CP, Zhou Q, Gao AC. 2012. Inhibition of Stat3 activation by sanguinarine suppresses prostate cancer cell growth and invasion. Prostate 72: 82-89. doi:10.1002/pros.21409

Sun Y, Atas E, Lindqvist LM, Sonenberg N, Pelletier J, Meller A. 2014. Single-molecule kinetics of the eukaryotic initiation factor $4 \mathrm{Al}$ upon RNA unwinding. Structure 22: 941-948. doi:10.1016/j.str 2014.04.014

Tillotson J, Kedzior M, Guimarães L, Ross AB, Peters TL, Ambrose AJ, Schmidlin CJ, Zhang DD, Costa-Lotufo LV, Rodríguez AD, et al. 2017. ATP-competitive, marine derived natural products that target the DEAD box helicase, elF4A. Bioorg Med Chem Lett 27: 4082-4085. doi:10.1016/j.bmcl.2017.07.045

Vogt A, Tamewitz A, Skoko J, Sikorski RP, Giuliano KA, Lazo JS. 2005. The benzo[c]phenanthridine alkaloid, sanguinarine, is a selective, cell-active inhibitor of mitogen-activated protein kinase phosphatase-1. J Biol Chem 280: 19078-19086. doi:10.1074/jbc.M5014 67200

Wendel HG, De Stanchina E, Fridman JS, Malina A, Ray S, Kogan S, Cordon-Cardo C, Pelletier J, Lowe SW. 2004. Survival signalling by Akt and elF4E in oncogenesis and cancer therapy. Nature 428: 332-337. doi:10.1038/nature02369 
White DE, Stewart IC, Grubbs RH, Stoltz BM. 2008. The catalytic asymmetric total synthesis of elatol. J Am Chem Soc 130: 810-811. doi:10.1021/ja710294k

Yoder-Hill J, Pause A, Sonenberg N, Merrick WC. 1993. The p46 subunit of eukaryotic initiation factor (elF)-4F exchanges with elF-4A. J Biol Chem 268: 5566-5573.

Yun SJ, Kim H, Jung SH, Kim JH, Ryu JE, Singh NJ, Jeon J, Han JK, $\mathrm{Kim} \mathrm{CH}$, Kim S, et al. 2018. The mechanistic insight of a specific interaction between 15d-Prostaglandin-J2 and elF4A suggests an evolutionary conserved role across species. Biol Open 7: bio035402. doi:10.1242/bio.035402

Zeder-Lutz G, Choulier L, Besse M, Cousido-Siah A, Ruiz Figueras FX, Didier B, Jung ML, Podjarny A, Altschuh D. 2012. Validation of surface plasmon resonance screening of a diverse chemical library for the discovery of protein tyrosine phosphatase $1 \mathrm{~b}$ binders. Anal Biochem 421: 417-427. doi:10.1016/j.ab.2011.09.015 

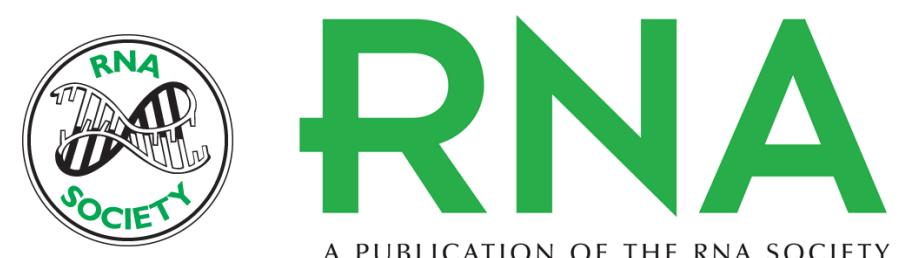

A PUBLICATION OF THE RNA SOCIETY

\section{A comparative study of small molecules targeting elF4A}

Sai Kiran Naineni, Rayelle Itoua Maïga, Regina Cencic, et al.

RNA 2020 26: 541-549 originally published online February 3, 2020

Access the most recent version at doi:10.1261/rna.072884.119

Supplemental Material

References

Creative Commons License

Email Alerting Service
http://rnajournal.cshlp.org/content/suppl/2020/02/03/rna.072884.119.DC1

This article cites 57 articles, 15 of which can be accessed free at: http://rnajournal.cshlp.org/content/26/5/541.full.html\#ref-list-1

This article is distributed exclusively by the RNA Society for the first 12 months after the full-issue publication date (see http://rnajournal.cshlp.org/site/misc/terms.xhtml). After 12 months, it is available under a Creative Commons License (Attribution-NonCommercial 4.0 International), as described at http://creativecommons.org/licenses/by-nc/4.0/.

Receive free email alerts when new articles cite this article - sign up in the box at the top right corner of the article or click here. 